\title{
Wooden Objects in Architecture Competitions
}

\author{
Arnoldas Gabrėnas, Darius Linartas \\ Vilnius Gediminas Technical University, Lithuania
}

Corresponding e-mail: arnoldas.gabrenas@gmail.com

\author{
Article info: \\ Received: 03-08-2020, Revised: 01-09-2020, Accepted: 14-09-2020
}

\begin{abstract}
The article deals with the role of wooden architecture constructions in competitions that took place in the recent decade. Architecture competitions for which designs from wood were offered are discussed. This article is based on the research of three international competitions and three local competitions. Analysis of the wooden architecture helps to find important aspects and to see the changing value of it during the time. It should be noted that wooden constructions, owing to their properties, are increasingly noticeable and are acknowledged with awards. Competitions are the field where architects are free to express their visions, make innovative decisions, propose unexpected materials. Achievements show solutions that experts, property developers, and society are ready to accept. Given that this process takes place in architecture competitions, we can predict architectural trends in the near future.
\end{abstract}

Keywords: wooden materials, architecture competition, sustainability, innovative, promising

\section{Introduction}

Architecture competitions can be useful as identifiers of a separate type of cultural production since they show the situation in a hyperbolized way (Lipstadt, 2003). The architects' relationship with competitions is special. It has been noticed that, unlike the representatives of other artistic professions, the architects willingly take an active part in competitions since this practice gives them more freedom in their creation and more artistic independence. H. Lipstad comes to the reasonable conclusion that architecture competitions represent a particular creative field where, like in no other field, architects can become relatively autonomous creators independent of the political and economic situation or the direct influence of the customer. Hence, if it were namely creative competitions that would be singled out in the entire architectural practice, they would become the chain connecting architecture with other socalled pure arts that Pierre Bourdieu explains based on the homological theory of humanitarian issue fields. For the architects, participation in creative competitions is a means of the accumulation of a symbolic capital (Bourdieu, 1996), which helps them hold higher positions not just in a competition, but also in their creative, professional activities, and at the same time use the standing gained and their abilities in real works. Hence, apart from the direct meaning (implemented objects), competitions are where the future architectural vision and the professionals capable of achieving it are indirectly formed, given the trends.

Most architects (Anthony, 1991; Baravykas, 1985; Spreiregen, 1979; Strong, 1996; Vaitys, 2005; Žickis, 1996) define competitions as an incubator of new ideas, a means of dissemination, a factor of an advance in creative thought: " <...>during competitions, new ideas are generated, they are compared to colleagues' thoughts, and this becomes a peculiar engine 
of progress <... >" (Čaikauskas, 1999). However, architects are not the only party that takes part in a competition. Where the competition is full-fledged, it becomes a kind of public consensus: a consolidated opinion of the customers, professional architects, public representatives, and decision makers are generated (Logvinov\&Kudriavcev, 2006). In this respect, the goal is to balance the influence of all the parties involved. It can thus be stated that the results of a competition not only show the prevailing creative ideas of the architects, but also the social order, the relevance of some solutions or others.

Since architecture competitions become a field of the conflict of the very different interests (interests of property developers, designers, social groups and authorities) mentioned above, the competition tendencies observed may help disclose the features of the most-up-to-date and much more global phenomena. One of the peculiarities of contemporary competitions, is the increasing number of wooden architecture among winning designs.

\section{Methods}

The work should be attributed to the area of interdisciplinary research. It has applied the method of structural analysis, which allowed for finding out unanimous structural consistent patterns of the research subject. The method of comparative analysis has helped to identify the common features of contemporary wooden objects. The research has been carried out by the method of inductive analysis starting with separate facts and generalize the information. The authors have also based his research on the analysis and selection of international source texts, illustrations and drawings, exploration of the objects concerned in situ, photo-fixations of the objects, generalization and systematization of the collected materials. This work is based on the research of three international competitions and three local competitions. The part of these competition projects are created by international teams of architects and other designers. Mentioned projects are winners of the competitions so there are awarded, published works, indicating and determining trends in nowadays architecture.

\section{Discussion}

Among the cases discussed more widely in the recent decade, when talking about wooden architecture took place as the winner were the architecture competition for the extension of the Serlachius Museum (Manta, Finland, winner MX-SI architectural studio and "Huttunen-LipastiPakkanen", 2011 y.), HSB Stockholm architectural competition (Stockholm, Sweden, winner C.F. Møller Architects, in collaboration with Dinell Johansson, 2013 y.), Modern Art Museum in Odunpazari (Turkey, winner Kengo Kuma, 2017 y.) and Parking House competition (Aarhus, Denmark, winner JAJA architects together with Rama Studio and Søren Jensen Engineers, 2019 y.). We will discuss more the extension of the Serlachius Museum and Modern Art Museum in Odunpazari because these public buildings are already built and are available for the big number of visitors also like the message about the possibilities of wood in contemporary architecture. The objective of the Serlachius Museum extension competition, which took part in 2011, was a design for the additional block to the already existing Museum building. 579 designs from all over the world participated in the international competition, and the combined offer of the architects of the MX-SI architectural studio and "Huttunen-Lipasti-Pakkanen"was selected as the most suitable (see Figure 1). The winners' work attracted judges' attention with its laminated fir-tree wood framework as the main structure of the building, which looked particularly more attractive in visual terms against the interior and exterior of the expressive tectonics. More over, wood in the architecture of the new building was in harmony with the scenery and the local tradition of wood construction. The suggested wooden framework obviously differed from the Museum's current traditionally shaped brick building in its architectural expression; therefore, the relationship between these two constructions was easily comprehensible; it marked clearly the phases of the Museum development and their period. The choice in the competition seems to have been right, as the architecture of the 
building upon its construction was awarded with the prestigious MIES VAN DER ROHE award in 2015 (Rohe, 2015).

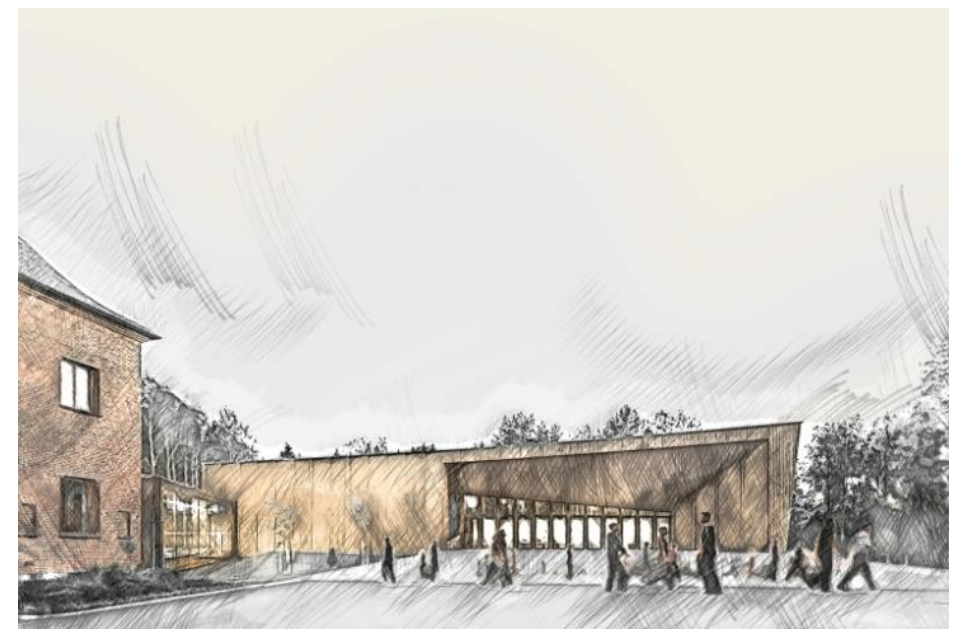

Figure 1. The winner of 1st prize in the architecture competition for the extension of the Serlachius Museum (Manta, Finland);architects MX-SI and Huttunen-Lipasti-Pakkanen, 2011.

It also worth mentioning the open international competition for the design of the Modern Art Museum in Odunpazari (Turkey) which took place in 2017, the winner of which was also a wooden structure (Fig. 2). The Odunpazari Modern Art Museum with an area of $3.582 \mathrm{~m}^{2}$ to be constructed in the city of Eskisehirwas to house one of Turkey's private modern art collections. The site of the Odunpazari Modern Art Museum was on the intersection of a territory developed in an new way of urban planning with a traditional Ottoman wooden building all around, which is characterized by consoles above the ground floor and an arrangement along narrow winding streets (PILOTAS, 2017). In designing this Museum, the architect Kengo Kuma conveyed these peculiarities of the townscape by means of modern architecture. There used to be a timber market on this site as well, which also undoubtedly inspired the architectural expression of the Museum. The mass of the Museum, is composed as if of wooden boxes put one onto another, and matches the scale of the street. The composition of wooden segments of a different size and facing different sides allowed the architects to design the necessary exhibition spaces inside (González, 2019). The Museum was built in 2019 is a nice example of the contemporary building achieved harmony with a local townscape. Wooden boxes are an attractive interpretation of the historical architecture that existed in the area. Also, wooden boxes are very important to interior space. Timber pieces with the same dimensions are shifted slightly, creating a warm and dynamic ambiance not found in conventional art museums. 


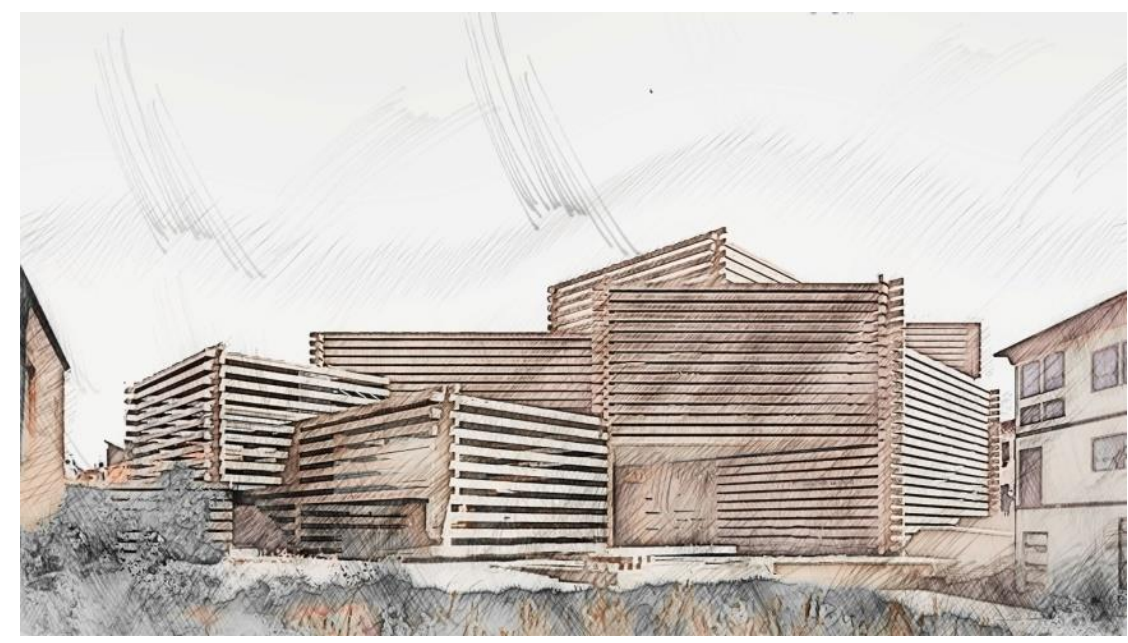

Figure 2. The winner of 1 st prize in the international competition for the design of the Odunpazari Modern Art Museum; architect Kengo Kuma, 2017

There are 0-14 architectural competitions every year in Lithuania (organized by Lithuanian Architects' Union). Most of them have some small wooden details, as facades, parts of facades, interiors, landscape elements. We chose to discuss those rare objects which have not only details but the main wooden structures too. In Lithuania, one of the first wooden objects to win in an architecture competition not only in the 1990s, but after the reinstatement of independence in general, was the observation tower in Anykščiai (see Figure 3). In their explanatory note, the authors of the design which won first prize in the competition which took place in 2011 wrote that the framework of the tower consists of equilateral triangular shaped plywood frames interconnected by metallic joints; the furbishing of the facades - wooden squared beams - are fixed on the inner side of the framework; the height of the construction was to be almost 36 meters. According to the idea, the highly elevated shape of a cut out silhouette was to embody the image of a grass-snake. The authors emphasized the importance of the tower's wooden openwork-finishing in particular; it was supposed to give the impression of the construction being surrounded in mist, to give it the sensation of lightness, hanging in the air (Bružas, 2011). The tower, which could become one of the highest wooden constructions in Lithuania, has not been built, but, it seems, attention has been paid to the suitability of wood for these types of constructions. The suitability for construction, contextualization, and harmony with Lithuanian scenery, tradition, and culture has been noticed. In later years, quite a few of the designs in Lithuania for an observation tower had wood applied at least for their finishing, and sometimes, for the partial supporting construction as well. 


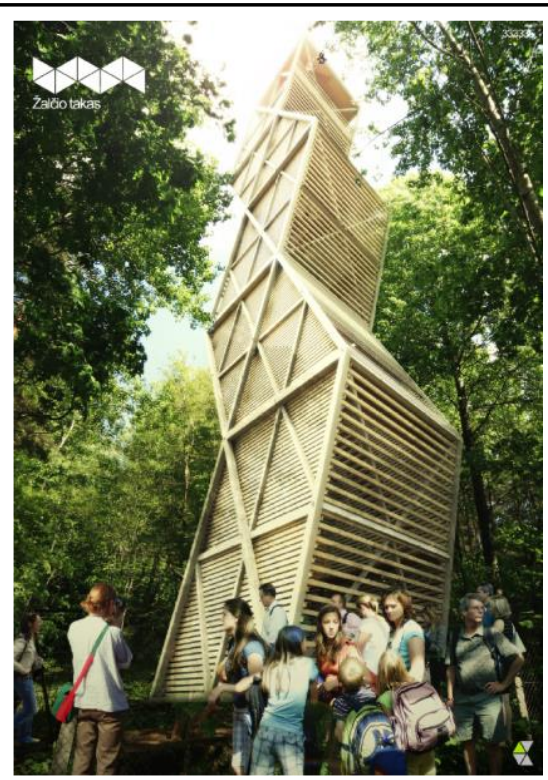

Figure 3. Design for the Treetop Walking Path in Anykščiai, 1st prize; view of the tower; architects Dž. Kisielius, I. Lukauskis, G. Gumenikovaitè and K. Radiūnas, 2011.

In recent years' competitions, wood was also remembered as a material that perfectly matches the ideas of sustainable, green, and ecological architecture. In this respect, we should mention two designs that won first prizes in the competition for the design of the administrative building on Sèliu Street 48 in Vilnius in 2018. First prize went to the architects' studio"Arches", which presented the "Office Villas" design (see Figure 4). The authors proposed a contextual construction of glass and wood with sloping roofs. In their design, the glass facades and roofs covered wooden constructions inside the building. The winner of 2 nd prize, an international team, used wood not only for the internal constructions, but for the supporting structure visible in the facade of the buildingas well (see Figure 5). For the consistent use of wood as the material and for other solutions of a sustainable construction, this design also received a special award for the ideas of sustainability and Green Buildings (Jankaitytè, 2018).

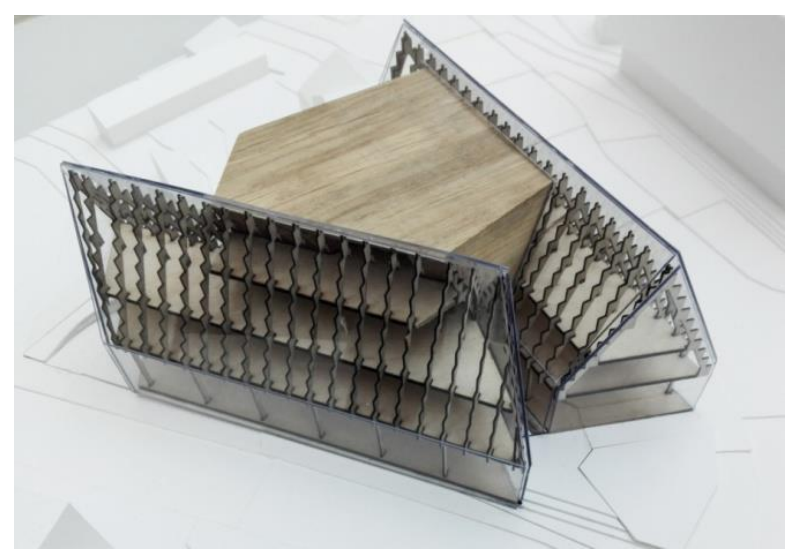

Figure 4. Model of the "Office Villas" design, 1st prize winner; architects "Arches", 2018 


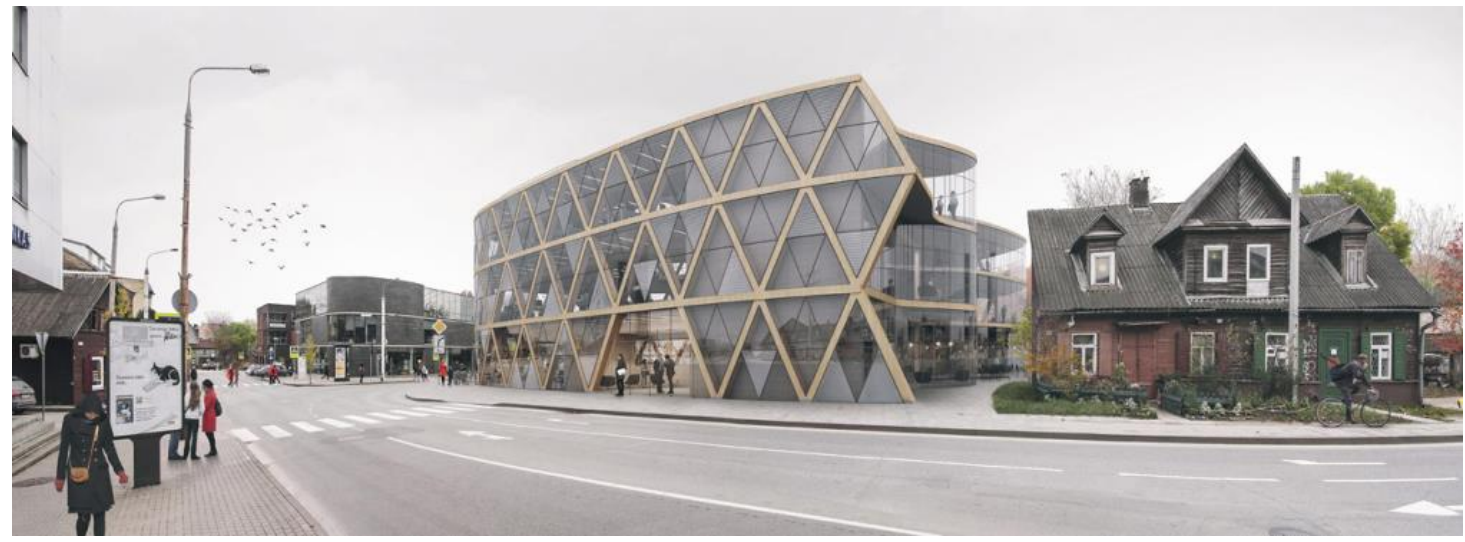

Figure 5. 2nd prize winner in the competition for the design of the administrative building on Sèliy Street 48 in Vilnius; architects L2 (Norway) and ARARTE (Lithuania), 2018

The increasingly hot discussions about the impact of human activities on the environment recently seem to make architecture competition participants and organizers pay more and more attention to the material. Wood becomes a material that gives a modern object a positive, friendly, and relevant image.

A competition for the design of the National Concert Hall "The Home of the Nation" was announced in Vilnius in 2019. Out of all the ideas for the National Concert Hall offered by 248 architects from around the world, the idea of the Spanish team "Arquivio Architects" was announced the winner of the competition by the International Evaluation Commission (Babkauskienè, 2019). The winning building consists of three major structures and is covered from the outside with aluminum and glass facades, but inside, part of the constructions are wooden. The roofing, columns, joists, and the elements of the decoration of the ceiling in the design are also wooden (see Figure 6). In the visualizations, it can be seen that the wooden elements make the interiors cozier and provide a peculiar warmth to them; at the same time, part of the materials in the building will be obtained from renewable sources; it will later be possible to deconstruct them without difficulty, to recycle, and to use them for other purposes.

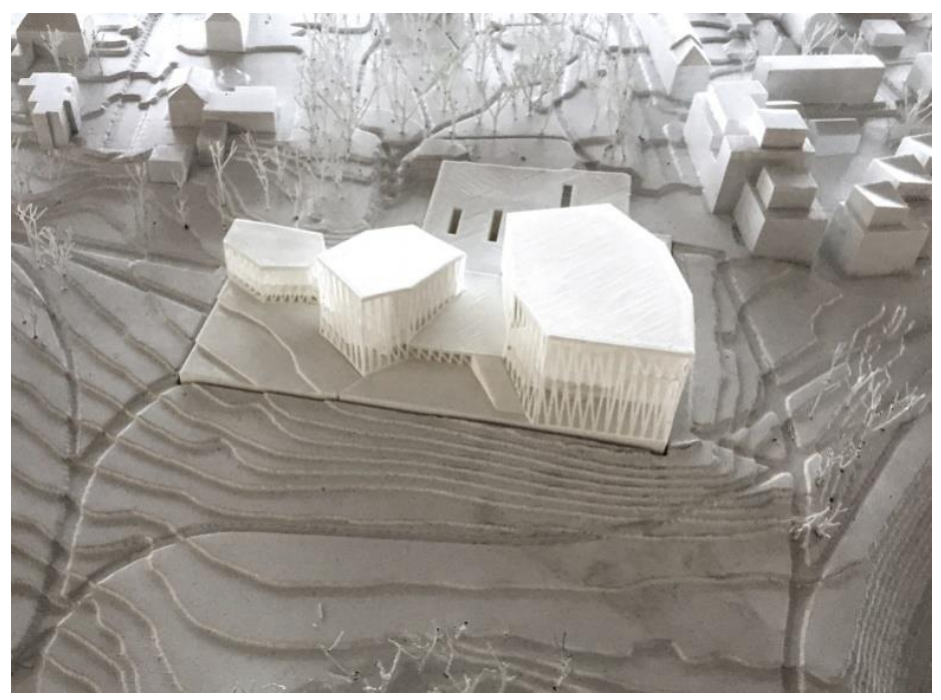

Figure 6. Model of the 1st prize winner in the international competition for the design of the National Concert Hall "The Home of the Nation"; architects "Arquivio architects", 2019 
Sustainable elements of wood were clearly evident in the design for the bridge across the River Neris from A. Goštautas Street to Upès Street by "INHUS Engineering"and "DO architects", which won first place in the architecture competition that took place in 2019. The idea of the architects was that the main construction of the bridge should be produced from wood - a local renewable material, which not only does not emit $\mathrm{CO} 2$ but absorbs it as it grows. According to the authors, such bridge is a symbolic continuation of the wooden architecture of Žverrynas.Thebridge will connect three residential districts: Saltoniškès on the right shore of the Neris, Žvèrynas, and Lukiškès on the left shore of the Neris, providing an important connection for the pedestrians and bicyclists. Based on the new Master Plan for Vilnius City solutions, it will also be part of the important bicycle path connection between central Vilnius and western residential areas. The new bridge will be adapted for the disabled; about three meters of its width will be given to pedestrians, four meters - to bicyclists (The Lithuanian Union of Architects, 2019). In its assessment report, the Commission of the competition noticed and singled out the innovative character of the bridge and its compliance with the principle of sustainable development. It accentuated the plywood material as a unique choice for Vilnius that wouldgive the new bridge exceptional features, novelty, and sustainability (in terms of the use of renewable and local resources).It also noted that the arch-like lower curve of the bridge allows one to avoid building work in the river during the construction process (Pakalnis, 2019). Hence, this competition drew attention to another important yet quite rarely remembered property of wood - its easiness of construction and are lated lesser environmental impact during the construction or use of the object (see Figure7).

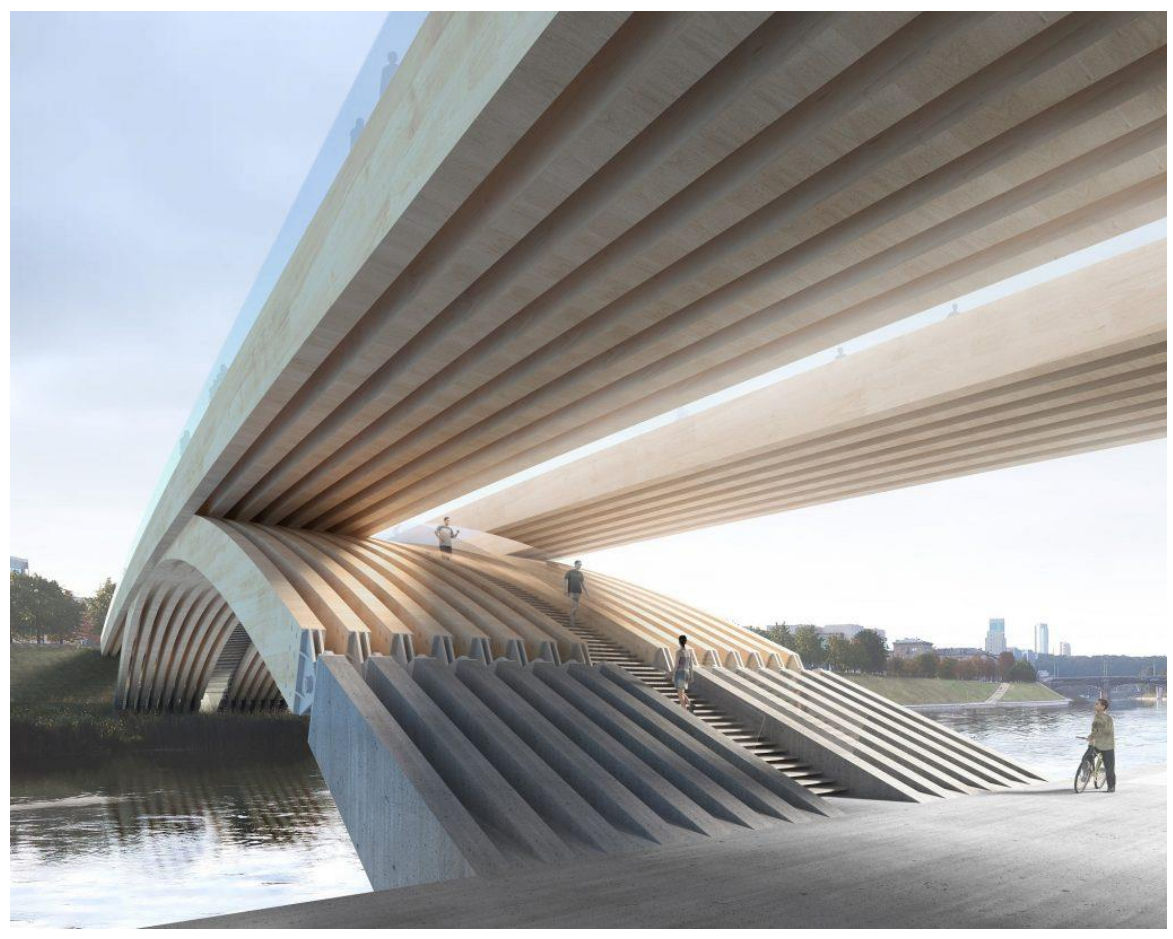

Figure 7. Design for the competition for the bridge across the River Neris from A. Goštauto Street to Upès Street, 1st prize, view of the bridge; architects "Do architects", 2019

Following discussed competition examples, we can find aspects of using wood in architecture objects. These aspects are the motives for the choice of wooden architecture for better, higher quality design results. The aesthetic properties of wooden structures were very important in the extension of the Serlachius Museum. In this object wooden elements mostly look particularly attractive in visual terms has expressive tectonics and have expressive contrast besides other materials. In the Modern Art Museum in Odunpazari wood structures are a very 
important sign of contextualization. This example shows using wood as a way to find relations with some countries or locations, where wood is a traditional material related to the significant aspect of identity. This aspect is important in Design for the Treetop Walking Path in Anykščiai, but in this object also we can see wood as a material having deep relations with cultural heritage, symbols, and myths. And then we have administrative buildings on Sèliu Street 48 in Vilnius where the sustainability aspect is very important and it is in very deep connection with the using wood in structures of these buildings. Wood here is a sign of "green building", a local material, accumulated experience in regional production and production potential, easy manufacturing, and utilization. When we discuss the projects of the National Concert Hall and Bridge across the River Neris aspect of sustainability can be supplemented with meanings of ecology and innovativeness. Where wood a renewable resource, which not only does not emit $\mathrm{CO} 2$ but absorbs it as it grows and still a novelty in today's construction and furnishing materials market.

\section{Conclusion}

Based on the motives behind the choice of wooden architecture in architecture competitions indicated by the authors of the designs or by the Assessment Commission, the following can be differentiated: wood has aesthetical properties, is related to context and culture, and nowadays is the sign of sustainability (with additional meanings of ecology and innovativeness).

The examples of specific designs for competitions discussed in the article illustrate the development of the change of the motives behind the choice of wooden architecture. If earlier, the aesthetic and cultural side of wood in architecture, and the contextualization of wooden architecture in respective situations were rather accentuated, in recent years, the suitability of this material in the creation of sustainable, ecological, and innovative constructions has increasingly been drawing attention.

The current need to reconsider humankind's existence in the world, the relationship between human needs and nature and natural resources, and the accelerating climate change, make the architects consider other trends in the development of architecture. Since architecture competitions are peculiar identifiers of trends in up-to-date creative thought and of its relevance for the society at large - judging from the increase in wooden objects that won competitions or won awards in them - we can assume that this material better and better corresponds to the needs of the present time. At the same time, it can be predicted that objects of wooden architecture will keep increasing in the near future as architects' award-winning visions in competitions are realized.

\section{References}

Anthony, K. H. (1991). Desig juries on trial: The renaissance of the design studio. New York: Van Nostrand Reinhold.

Babkauskienè, I. (2019). Ant Tauro kalno - ispany̨ „Tautos namai“ -Respublika.It - žinių portalas. Retrieved December

Baravykas, Gediminas. (1985). 4 klausimai kūrẻjams. Statyba ir architektūra, 85/11, 18.

Bourdieu, Pierre. (1996). The Rules of Art: Genesis and Structure of the Literary Field (Susan Emanuel, Trans.). Stanford, CA: Stanford University Press.

Bružas, A. (2011). LAIMĖJO „ŽALČIO TAKAS“//PASKELBTI ANYKŠČIŲ LAJŲ TAKO KONKURSO LAUREATAI - $\quad$ PILOTAS.LT.Citing Internet 
sources URLhttp://pilotas.It/2011/10/06/archyvas/2011/laimejo-zalcio-takaspaskelbtianyksciu-laju-tako-konkurso-laureatai/

Čaikauskas, Gintaras.(1999). Konkursas- susibėgimas ar susidūrimas? Archiforma, 99/3, 9596.

Jankaitytè, G. (2018). Paskelbti verslo centro Žvèryne architektūrinio konkurso nugalètojai Verslo žinios.Citing Internet sources URLhttps://www.vz.It/nekilnojamasis-turtasstatyba/2018/03/05/paskelbti-architekturinio-konkurso-verslo-centrui-zverynenugaletojai

LietuvosArchitektųSajunga. (2019). Išrinktas dar vieno tilto Vilniuje projektas - Lietuvos architektų sajunga. Citing Internet sources URLhttp://www.architektusajunga.It/konkursai/las-konkursai/isrinktas-darvieno-tilto-vilniuje-projektas/

Lipstadt, Hélène. (2003). Can 'art professions' be Bourdieuean fields of cultural production? The case of the architecture competition. Cultural Studies, 17 (3/4), 390-418.

Logvinov, V. N., \& Kudriavcev, A. P. (2006). Symposium Bulletin. Paper presented at the The Laboratory of an Architectural Competition, Moscow, April 12-13, 2006.

PILOTAS. (2017). MEDINÉ DÉLIONÉ TURKIJOJE: K. Kuma nusilenkè istorijai, tradicijoms, masteliui - $\quad$ PILOTAS.LT. Citing Internet sources URLhttp://pilotas.It/2017/04/25/architektura/medine-delione-turkijoje-k-kumanusilenke-istorijai-tradicijoms-masteliui/

Spreiregen, Paul D. (1979). Design competitions. New York: Mc Graw-Hill.

Strong, Judith. (1996). Winning by design: architectural competitions. Boston: ButterworthHeinemann.

Rohe, F. M. van der. (2015).EU Mies Award. Citing Internet sources URLhttps://www.miesarch.com/work/581

Vaitys, Leonardas. (2005). Gintautas Juozas Telksnys. Architektas. Vilnius: Dailininku sajungos leidykla "Artseria".

Žickis, Alvydas.(1996). Architektūros projektų konkursai. Archiforma, 96/2, 86-88. 